\title{
Intelligence and executive functions in 9-10 year-old preterm children born with very low and extremely low birth weight
}

\section{ANETT NAGY $Y^{1,2,3 *}$ - MAGDA KALMÁR ${ }^{4}$ - ANNA MÁRIA BEKE ${ }^{3}$ - RÓZSA GRÁF ${ }^{1,5,6}$ - ENDRE HORVÁTH ${ }^{2}$}

${ }^{1}$ ELTE Eötvös Loránd University, Doctoral School of Psychology, Budapest

${ }^{2}$ ELTE Eötvös Loránd University, Bárczi Gusztáv Faculty of Special Education, Institute of Atypical Behaviour and Cognition, Budapest

${ }^{3}$ Semmelweis University, Department of Obstetrics and Gynaecology, Budapest

${ }^{4}$ ELTE Eötvös Loránd University, Institute of Psychology, Department of Developmental and Clinical Child Psychology, Budapest

${ }^{5}$ Péterfy Hospital, Department of Neonatal Intensive Care Unit II, Budapest

${ }^{6}$ University of Miskolc, Faculty of Arts, Miskolc

(Received: 18 December 2018, accepted: 8 April 2019)

Theoretical background: Premature birth is in the focus of research interest as it is the most common perinatal risk endangering the development of children. However, the implications of prematurity for the long-term outcome are far from fully understood. Compromised development of cognitive and executive functions may be underlying academic underachievement in school-age preterm children. Aim: to assess the school-age outcomes of Hungarian VLBW/ELBW preterm children in basic cognitive abilities and executive function as compared to typically developing, full-term children as well as to investigate the background of individual differences. Method: 54 preterm children (27 ELBW, 27 VLBW) and a matched group of 27 healthy full-term children, aged 9-10 years, were tested using the Wechsler Intelligence Scales for Children (WISC-IV), the Corsi Block Tapping Task (digital version) for measuring spatial-visual working memory and the Wisconsin Card Sorting Test (WCST, digital version) for testing cognitive flexibility. As background variables perinatal and socioeconomic factors were entered in the analysis. Results: In each measure of the WISC-IV all three groups performed in the normal range. The ELBW children displayed certain developmental lags. They scored significantly lower in the Full-Scale IQ and the Processing Speed than the other two groups, and in the Perceptual Reasoning and one measure of spatial-visual working memory as compared to the non-risk comparison group. Perinatal complications and maternal education were related to the outcome. Conclusions: With the improved perinatal care preterm children have fair chances for good developmental outcomes. However, the individual variations

\footnotetext{
* Corresponding author: Anett Nagy, ELTE Eötvös Loránd University, Bárczi Gusztáv Faculty of Special Education, H-1097 Budapest Ecseri út 3. E-mail: anett.barczi@gmail.com
} 
are great and various perinatal and social factors may hamper the development of cognitive and executive functions. A birthweight below 1000 grams is a notable risk, particularly if combined with perinatal complications.

Keywords: prematurity, IQ, working memory, cognitive flexibility, perinatal complications

\section{Introduction}

According to an international consensus neonates born before the 37th week of gestation are considered preterms. Prematurity is the most common perinatal risk: the average rate of preterm births is between $9 \%$ and $12 \%$ of all live births in the higher- and lower-income countries, respectively (WHO, 2018). In Hungary $8,1 \%$ of the newborn babies were preterms in 2017 (HCSO, 2018).

The degree of risk for the development of the individual involved in premature birth depends on a range of factors. The population of premature babies is very heterogeneous. The earlier the baby is born and the less the birthweight, the greater the risk. According to the degree of immaturity three categories are distinguished: moderate to late preterms (gestational age [GA]: 32-37 weeks), very preterms (GA: 28-32 weeks), extremely preterms (GA < 28 weeks) $(\mathrm{WHO}, 2018)$. Birth weight serves as a basis for a classification of preterm neonates most frequently used in medical praxis according to the recommendation by the $\mathrm{BNO} 10$. The categories are the following: extremely low birth weight (BW < 1000 grams, ELBW); very low birth weight (1000-1499 grams, VLBW); low birth weight (1500-2499 grams, LBW) (Behrman \& Butler, 2007). The Hungarian figures regarding the distribution of the preterm neonates in 2017 were as follows: GA 32-37 weeks $84,6 \%$, GA $28-31$ weeks 10,4\%, GA $24-27$ weeks 4,5\%, GA < 24 weeks 0,5\%; normal birth weight (> 2500 g) $38 \%$, LBW 46,5\%, VLBW 8,7\%, ELBW 6,7\% (HCSO, 2018).

Perinatal complications may further increase the risk. The immature organism is more vulnerable to diseases affecting the respiratory organs (respiratory distress-syndrome, RDS), the central nervous system, and the sensory systems. The prevalence of the intraventricular haemorrhage (IVH) among the ELBW infants is 50\% (Balla \& Szabó, 2013) and the more immature the baby the IVH tends to be more severe (stades III and IV) with the rates of $39.9 \%$ in babies born at 24 weeks gestation, $24 \%$ at 26 weeks gestation, and $9.7 \%$ at 28 weeks gestation (Ertl, 2018). 14,1\% of the ELBW, while 11\% VLBW preterms suffer severe IVH (Behrman \& Butler, 2007; Glass et al., 2015). Periventricular white matter lesion (PVL) is a typical 
white-matter injury in preterm infants which, along with the more severe degrees of IVH, may cause cerebral palsy and the loss of oligodendroglial cells (Mulder, Pitchford, Hagger, \& Marlow 2009).

A chronic lung disease, bronchopulmonary dysplasia (BPD) is also a common concomitant of premature birth, occurring in more than $40 \%$ of ELBW preterms (Glass et al., 2015). The prevalence considerably varies across hospitals (in VLBW infants 3-43\%, Behrman \& Butler, 2007). The BPD most frequently occurs in preterm infants who require prolonged ventilatory support (Hargitai \& Marton, 2018). Ventilatory therapy (mostly by hyperoxia) may cause an abnormal vascular proliferation of the immature retina, leading to an ocular disease called retinopathy of prematurity (ROP) (Beke, 2019).

The development of the central nervous system in preterm infants deviates from that in their full-term counterparts. Anomalies are often found in the structure of both the white and the gray matter. The entorhinal cortex and the corpus callosum can be thinner (Feldman, Lee, Yeatman, \& Yeom, 2012; Skranes et al., 2012) and the volume of the hippocampus (Beauchamp et al., 2008) as well as that of the cerebellum can be smaller than in term newborns (de Kieviet, Zoetebier, Van Elburg, Vermeulen, \& Oosterlaan 2012). The effects of prematurity on the CNS development seem to differ across the brain regions. One region may be affected severely while others may remain intact. In low-risk preterm infants there were no significant differences in the volume of the dorsal prefrontal and the orbitofrontal lobe which are related to the executive function (Peterson, 2000).

It is apparent that the neurodevelopmental consequences of premature birth affect the development of cognitive functions and academic abilities, although the bulk of research evidence is not consistent. The IQs of the VLBW/ELBW preterm children as a group were found to fall into the average (Grunewaldt et al., 2014) or low-average zone (Stålnacke, Lundequist, Böhm, Frossberg, \& Smedler, 2018). However, according to a recent meta-analysis reviewing 71 studies comparing the IQs of very preterm children to those of term comparison groups the preterms significantly lagged behind (Twilhaar et al., 2018). The authors of the metaanalysis also noted the heterogeneity of results across studies. In the studies by Grunewaldt et al. (2014) and Rushe et al. (2001), e.g., the preterms had deficits only on a single cognitive measure out of several ones.

Research interest in executive functions (EFs) - which is an umbrella term encompassing the conscious, goal-directed problem-solving thinking and the higher-order control processes (Zelazo, Carlson, \& Kesek, 2008) - is 
relatively recent. A universally accepted theoretical model of EF is not yet available, but inhibition, working memory, and cognitive flexibility have been generally regarded as its core components (Diamond, 2013). As inhibition failed to explain variance above the common EF factor it was omitted from a revised model which consists of a shifting specific factor (cognitive flexibility) and an updating specific factor (working memory) (Miyake \& Friedman, 2012; Stålnacke et al., 2018). The importance of EF is increasingly recognized since EFs have been found to influence school readiness more strongly than IQ (Blair \& Razza, 2007).

Premature birth involves a risk for executive deficits. Four year-old preterm children performed more poorly than the term comparison group on direct measures of EF, and their teachers reported that they had more difficulties with inhibition, working memory, planning/organisational skills, and self-control (O'Meagher, Kemp, Norris, Anderson, \& Skilbeck, 2017). School-age ELBW/VLBW preterms scored poorer as compared to their non-risk counterparts in tasks requiring inhibition, working memory, and shifting (i.e., cognitive flexibility) (Aarnoudse-Moens, Duivenvoorden, Weisglas-Kuperus, van Goudoever, \& Oosterlaan, 2011; Ford et al., 2011; Stålnacke et al., 2018). In the study of Ritter, Nelle, Perrig, Steinlin and Everts (2013) 8-10 year-old VLBW children performed significantly poorer than the controls in inhibition, working memory, and shifting, whereas the 10-13 year old VLBW children reached the same level as the controls in all three EFs. The authors concluded that the poor performances of the younger VLBW children might reflect a delay rather than a deficit. The catch-up tendency presumably stems from the plasticity of function and organisation of the human brain (Ford et al., 2011). In addition, Ritter and colleagues (2013) argued for the potential remedial effects of environmental factors. The age of the subjects may explain the results reported by Rushe and colleagues (2001), conflicting the majority of findings presented in the literature. In this research 14-15 year-old adolescents who were born very preterm, even those with MRI abnormalities performed in the normal range on measures of EFs. The study by Costa and colleagues (2017) calls attention to the variety of developmental trends of executive functions in ELBW children. In the majority of their subjects the EFs remained stable between 8 and 18 years of age, with more than half of them scoring in the typical range and $15 \%$ performing persistently low. However, the EF performances of about $1 / 4$ of the subjects changed markedly, with late-onset difficulties and remitting trends occurring in equal proportions.

The substantial inter-individual variations within the preterm children underline the issue of prediction of the development of EFs. O'Meagher et al. (2017) found that social risks, particularly low maternal education were the strongest associates of impaired EF outcomes while the perinatal 
variables had no predictive power. In contrast, a study by Ford et al. (2011) provided evidence on the impact of neurobiological risks on EF performances and revealed interactions between neurobiological risk factors and maternal education in ELBW children. It suggests that the adverse effects of neurobiological risks can be attenuated by favourable social backgrounds. A recent 18-year long longitudinal study by Stålnacke and colleagues (2018) revealed a complex mechanism underlying the development of EFs, using a serial multiple mediator model. The results showed a remarkable stability of both working memory and cognitive flexibility from $5 \frac{1}{2}$ to 18 years of age. Parental education had direct effect on both $5 \frac{1 / 2-y e a r}{2}$ EF measures, while perinatal medical complications and intrauterine growth had direct effects on cognitive flexibility at 18 years. In addition, mental development at 10 months of age mediated the influences of perinatal variables and gender by having direct relation to the $5 \frac{1}{1 / 2}$-year EF measures.

The aim of our study was to evaluate the school-age outcomes of Hungarian VLBW/ELBW preterm children in basic cognitive abilities and executive function as compared to typically developing, full-term children. The assessment of the EF was based on the revised model proposed by Miyake and Friedman (2012), distinguishing two specific factors, a shiftingspecific and an updating-specific factor, i.e., cognitive flexibility, and working memory. We were attempting to tap the background of individual differences in the outcomes by analysing the effects of perinatal and socialeconomic factors.

\section{Method}

The study was approved by the Scientific and Research Ethics Committee of the Health Science Council (13425-2/2016/EKU)

\subsection{Subjects}

The subjects were 81 children, aged 9-10 years. 54 children were born preterm. The majority of the preterm sample were participants in the follow-up program of the Department of Obstetrics and Gynaecology, Semmelweis University, Budapest. Further subjects were recruited via the internet. Half of the preterm sample was born with birthweights $<1000$ grams (ELBW) and the other half with birthweights between 1000-1499 grams (VLBW). The perinatal characteristics and complications are shown in Table 1. 
Table 1. Perinatal characteristics and complications of the preterm groups

\begin{tabular}{|c|c|c|c|}
\hline & ELBW & VLBW & $\begin{array}{c}\text { Comparison } \\
\text { statistics }\end{array}$ \\
\hline $\begin{array}{l}\text { Birth weight (BW) } \\
\text { Mean } \\
\text { SD } \\
\text { Range }\end{array}$ & $\begin{array}{l}825 \text { grams } \\
109.6 \\
550-990\end{array}$ & $\begin{array}{l}1260 \text { grams } \\
156.1 \\
1050-1490\end{array}$ & $\begin{array}{c}t(52)=-11.88 \\
p<0.0001\end{array}$ \\
\hline $\begin{array}{l}\text { Gestational age }(\mathrm{GA}) \\
\text { Mean } \\
\text { SD } \\
\text { Range }\end{array}$ & $\begin{array}{l}27 \text { weeks } \\
2.1 \\
24-32\end{array}$ & $\begin{array}{l}30 \text { weeks } \\
2.04 \\
28-34\end{array}$ & $\begin{array}{c}t(52)=-5.06 \\
p<0.0001\end{array}$ \\
\hline Bronchopulmonary dysplasia (BPD) & $8(30 \%)$ & - & $\begin{array}{c}\chi^{2}(1)=9.39 \\
p=0.002\end{array}$ \\
\hline $\begin{array}{l}\text { Intraventricular haemorrhage (IVH) } \\
\text { Mild } \\
\text { Severe }\end{array}$ & $\begin{array}{c}4(15 \%) \\
1(4 \%)\end{array}$ & $\begin{array}{c}4(15 \%) \\
2(7 \%)\end{array}$ & $\begin{array}{c}\chi^{2}(1)=0.36 \\
p=0.837\end{array}$ \\
\hline $\begin{array}{l}\text { Retinopathy of prematurity (ROP) } \\
\text { Mild } \\
\text { Severe }\end{array}$ & $\begin{array}{l}8(30 \%) \\
4(15 \%)\end{array}$ & $\begin{array}{c}8(30 \%) \\
-\end{array}$ & $\begin{array}{c}\chi^{2}(1)=1.27 \\
p=0.260\end{array}$ \\
\hline Small for Gestational Age (SGA) & $13(48 \%)$ & $6(22 \%)$ & $\begin{array}{c}\chi^{2}(1)=3.98 \\
p=0.046\end{array}$ \\
\hline
\end{tabular}

The non-risk comparison group (control) was recruited from schools. The criteria of inclusion were full-term birth, birth weight $>2500$ grams, lack of perinatal complications, and a typical developmental course. The 27 fullterm comparison children (FT) were born at 38-41 weeks gestation $($ mean $=$ 40; $\mathrm{SD}=1,2$ ), with birthweights of 2560-4320 grams (mean $=3501$; $\mathrm{SD}=$ 410). The three groups (ELBW, VLBW, FT) were matched on age, gender, and maternal education triad-wise. Each group consisted of 11 boys and 16 girls. The ages of the children in each group were the following: ELBW mean 113 months (SD = 3,14; range 108-118), VLBW mean 114 months (SD $=3,96 ; 108-119)$, FT mean 113 months (SD = 3,49; range 108-119). As far as maternal education is concerned, in each group $7 \%$ of the mothers completed general school, $7 \%$ had vocational school certificate, $7 \%$ passed matriculation, and $59 \%$ had college or university degree.

All of the children attended mainstream general schools and none of them was diagnosed with ADHD or learning disability. 


\subsection{Instruments and procedure}

The instruments were the Wechsler Intelligence Scales for Children (WISCIV; Wechsler, 2008), the Corsi Block Tapping Task (Corsi, 1972; Milner, 1971) for measuring spatial-visual working memory (ie, the updatingspecific factor of EF) and the Wisconsin Card Sorting Test (WCST; Grant \& Berg, 1948; Heaton, Chelune, Talley, Kay, \& Curtiss, 1993) for testing cognitive flexibility (ie, the shifting-specific factor of EF).

The tests of executive functions were administered in digital versions (PEBL version 0.13 test package (Mueller \& Piper, 2014) using a personal computer (PC Intel Core i7 $2.8 \mathrm{GHz}$ with windows 7, 64 bit operating system; with a BenQ V4200 Eco monitor of 1920x1080 resolution).

In the WCST four target cards differing in colour, shape, and number were shown at the top of the screen. Below the four cards which remained the same in the entire test a 5th one appeared which was different in each trial. For each trial this 5 th card could be matched to different target cards based on similarity in one particular stimulus dimension in each card. However, in each trial only one sorting principle was correct according to a rule generated by the programme. The subject received a feedback after each match on whether or not it conformed to the principle. The task of the subject was to find out this principle. After 10 consecutive correct matches the rule changed. The sequence of the sorting principles was constant: color, form, and number. This sequence was repeated twice. The test ended either after the subject found the correct sorting principle six times or after matching 128 cards.

In the Corsi Block Tapping Task the subjects had to remember sequences of locations. Nine blue squares were shown irregularly arranged on the screen. In each trial certain target squares flashed in yellow, one at a time, in a sequence. The subject was instructed that after the sequence was finished $\mathrm{s} /$ he should click on each of the target squares in the same order as demonstrated ("forward" rule). The task started with a sequence of two squares, then the sequence increased one by one with two trials for each sequence length. The same task was repeated using the "backward" rule: the subject had to click on the target squares in reverse order relative to the demonstration.

The children were tested individually in the laboratory of the university with only the child and the tester psychologist (the first author) present. The session started with a short conversation about the child's experiences with computers. All of the children were familiar with the devices and the use of them caused no difficulty. As the children considered the digital tasks com- 
puter games the tasks proved to be quite attractive and motivating. After each test the children were allowed to have short breaks. Altogether the testing took $1 \frac{1 / 2}{2}$ hours.

\subsection{Measures}

WISC-IV: Full Scale IQ (FSIQ), Verbal Comprehension Index (VCI), Perceptual Reasoning Index (PeRI), Working Memory Index (WMI), Processing Speed Index (PrSI).

Corsi Block Tapping Task: Reaction time and the number of correct trials in the forward and backward tasks.

WCST: Number of completed categories, numbers of perseverational and non-perseverational errors).

Background variables: Perinatal characteristics and complications in the preterm children: birth weight, gestational age, bronchopulmonal dysplasia, intraventricular haemorrhage, rethinopathy of prematurity. The grades of the complications are indicated in the hospital reports. However, as the severe grades were scarce in the sample, the complications were included in the analysis as dichotomous variables.

Maternal education for representing the socioeconomic background: the 5 grades were (1) less than 8 completed classes of general school; (2) 8 completed classes of general school; (3) vocational school certificate; (4) matriculation; (5) college or university degree.

\subsection{Statistical analysis}

The data analysis was performed using the SPSS 22 (IBM, Armonk, NY, USA). The results were considered significant if $p<0.05$ (two-sided). The data had normal distributions for each variable.

The three groups were compared using a one-way MANOVA with Bonferroni correction. In order to test the contribution of the background variables to the results General Linear Models were computed. The first models (models 1) covered the total sample with gender and maternal education as independent variables. Further models (models 2) applied only to the preterm subjects aiming to check the role of perinatal variability. In this model maternal education, birth weight, gestational age, and the perinatal complications were included in the analysis. The dependent variables were WISC-IV FSIQ (models 1a, 2a), WISC-IV indices (models 1b, $2 b$ ), Corsi measures (models 1c, 2c) and WCST measures (models 1d, 2d). 


\section{Results}

The mean scores of each measure of the WISC-IV fell within the normal range in all three groups. The ELBW children scored significantly lower in the Full-Scale IQ and the Processing Speed Index than the other two groups, and in the Perceptual Reasoning Index and one measure of the Corsi Block Tapping Task as compared to the non-risk comparison group. The WCST did not discriminate the groups. The performances of each group are shown in Table 2.

Table 2. The performances of the three groups

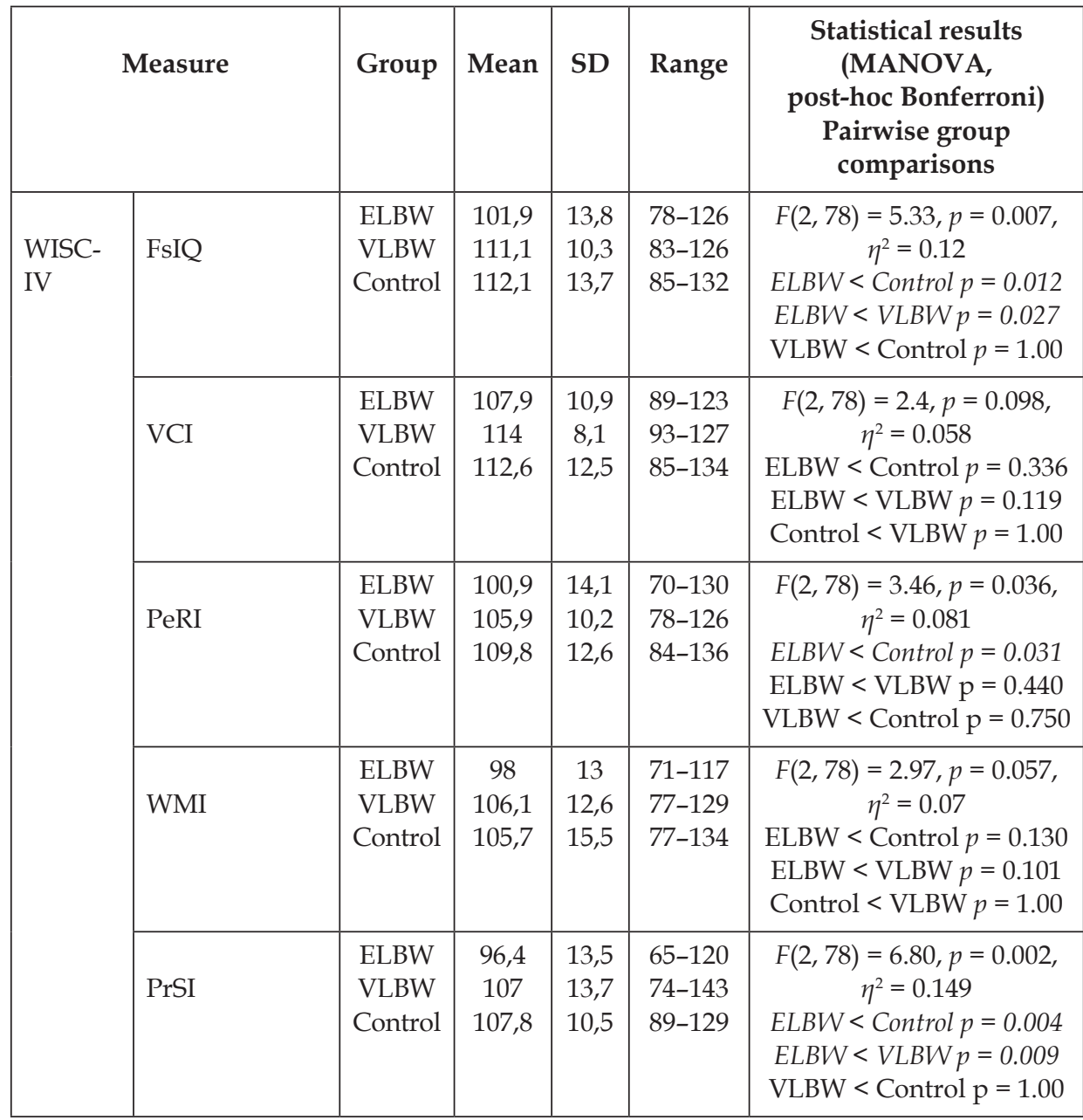




\begin{tabular}{|c|c|c|c|c|c|c|}
\hline \multicolumn{2}{|c|}{ Measure } & Group & Mean & SD & Range & $\begin{array}{l}\text { Statistical results } \\
\text { (MANOVA, } \\
\text { post-hoc Bonferroni) } \\
\text { Pairwise group } \\
\text { comparisons }\end{array}$ \\
\hline \multirow[t]{4}{*}{$\begin{array}{l}\text { Corsi } \\
\text { Block } \\
\text { Tapping } \\
\text { Task }\end{array}$} & $\begin{array}{l}\text { Reaction time } \\
\text { (sec) } \\
\text { forward }\end{array}$ & $\begin{array}{l}\text { ELBW } \\
\text { VLBW } \\
\text { Control }\end{array}$ & $\begin{array}{c}405,3 \\
402 \\
416\end{array}$ & $\begin{array}{l}44,1 \\
34,9 \\
21,2\end{array}$ & $\begin{array}{l}264-497 \\
310-474 \\
369-457\end{array}$ & $\begin{aligned} F(2,77)=1.21, p=0.303, \\
\eta^{2}=0.031 \\
\text { ELBW < Control } p=0.791 \\
\text { VLBW < ELBW } p=1.00 \\
\text { VLBW }<\text { Control } p=0.419\end{aligned}$ \\
\hline & $\begin{array}{l}\text { Correct trials } \\
\text { (number) } \\
\text { forward }\end{array}$ & $\begin{array}{l}\text { ELBW } \\
\text { VLBW } \\
\text { Control }\end{array}$ & $\begin{array}{l}5,5 \\
6,3 \\
6,6\end{array}$ & $\begin{array}{l}1,9 \\
1,5 \\
1,9\end{array}$ & $\begin{array}{c}2-8 \\
3-8 \\
2-10\end{array}$ & $\begin{array}{c}F(2,77)=2.31, p=0.106, \\
\quad \eta^{2}=0.057 \\
\text { ELBW }<\text { Control } p=0.118 \\
\text { ELBW }<\text { VLBW } p=0.425 \\
\text { VLBW }<\text { Control } p=1.00\end{array}$ \\
\hline & $\begin{array}{l}\text { Reaction time } \\
\text { (sec) } \\
\text { backward }\end{array}$ & $\begin{array}{c}\text { ELBW } \\
\text { VLBW } \\
\text { Control }\end{array}$ & $\begin{array}{c}401,9 \\
396,6 \\
407\end{array}$ & $\begin{array}{l}51,5 \\
33,5 \\
27,7\end{array}$ & $\begin{array}{l}207-498 \\
319-476 \\
356-491\end{array}$ & $\begin{array}{c}F(2,78)=0.48, p=0.621 \\
\eta^{2}=0.012 \\
\text { ELBW }<\text { Control } p=1.00 \\
\text { VLBW }<\text { ELBW } p=1.00 \\
\text { VLBW }<\text { Control } p=1.00\end{array}$ \\
\hline & $\begin{array}{l}\text { Correct trials } \\
\text { (number) } \\
\text { backward }\end{array}$ & $\begin{array}{l}\text { ELBW } \\
\text { VLBW } \\
\text { Control }\end{array}$ & $\begin{array}{l}6,1 \\
6,9 \\
7,3\end{array}$ & $\begin{array}{l}1,9 \\
1,7 \\
1,7\end{array}$ & $\begin{array}{c}2-10 \\
1-9 \\
4-11\end{array}$ & $\begin{array}{c}F(2,78)=5.21, p=0.008, \\
\eta^{2}=0.118 \\
E L B W<\text { Control } p=0.006 \\
\text { ELBW }<\text { VLBW } p=0.285 \\
\text { VLBW }<\text { Control } p=0.386\end{array}$ \\
\hline \multirow[t]{3}{*}{ WCST } & $\begin{array}{l}\text { Completed } \\
\text { categories } \\
\text { (number) }\end{array}$ & $\begin{array}{l}\text { ELBW } \\
\text { VLBW } \\
\text { Control }\end{array}$ & $\begin{array}{l}5,1 \\
5,1 \\
5,3\end{array}$ & $\begin{array}{l}2,5 \\
2,2 \\
2,4\end{array}$ & $\begin{array}{l}0-9 \\
1-9 \\
2-9\end{array}$ & $\begin{array}{c}F(2,78)=0.45, p=0.642 \\
\eta^{2}=0.011 \\
\text { ELBW }<\text { Control } p=1.00 \\
\text { ELBW }=\text { VLBW } p=1.00 \\
\text { VLBW }<\text { Control } p=1.00\end{array}$ \\
\hline & $\begin{array}{l}\text { Number of } \\
\text { perseverational } \\
\text { errors }\end{array}$ & $\begin{array}{c}\text { ELBW } \\
\text { VLBW } \\
\text { Control }\end{array}$ & $\begin{array}{l}23,4 \\
21,4 \\
19,8\end{array}$ & $\begin{array}{c}11,7 \\
9,2 \\
7,9\end{array}$ & $\begin{array}{c}0-54 \\
7-50 \\
11-48\end{array}$ & $\begin{array}{c}F(2,78)=0.92, p=0.403, \\
\eta^{2}=0.023 \\
\text { Control }<\text { ELBW } p=0.538 \\
\text { VLBW }<\text { ELBW } p=1.00 \\
\text { Control }<\text { VLBW } p=1.00\end{array}$ \\
\hline & $\begin{array}{l}\text { Number of } \\
\text { non- } \\
\text { perseverational } \\
\text { errors }\end{array}$ & $\begin{array}{c}\text { ELBW } \\
\text { VLBW } \\
\text { Control }\end{array}$ & $\begin{array}{l}17,4 \\
17,8 \\
13,3\end{array}$ & $\begin{array}{c}16,5 \\
9,6 \\
7,2\end{array}$ & $\begin{array}{l}1-86 \\
5-37 \\
2-27\end{array}$ & $\begin{aligned} F(2,78)=1.21, p=0.305 \\
\eta^{2}=0.03 \\
\text { Control }<\text { ELBW } p=0.609 \\
\text { ELBW }<\text { VLBW } p=1.00 \\
\text { Control }<\text { VLBW } p=0.497\end{aligned}$ \\
\hline
\end{tabular}

Note: ELBW = extremely low birth weight (<1000 grams), VLBW = very low birth weight (1000-1499 grams), WISC-IV = Wechsler Intelligence Scales for Children, FSIQ = Full Scale $\mathrm{IQ}, \mathrm{VCI}=$ Verbal Comprehension Index, PeRI = Perceptual Reasoning Index, WMI = Working Memory Index, PrSI = Processing Speed Index, WCST $=$ Wisconsin Card Sorting Test. 
In searching for the background of the performances and the explanation of the massive within-group scatters of scores General Linear Models were computed.

According to the models covering the total sample (Table 3) gender had no significant effect on any of the dependent variables, while maternal education was a significant covariate for each measure of the WISC-IV and two measures of the Corsi Block Tapping Task.

Table 3. General Linear Models: Total sample

\begin{tabular}{|c|c|c|c|c|c|}
\hline Model & \multicolumn{2}{|r|}{ Measure } & Independent variables & $F(\mathrm{df})$ & $p$ \\
\hline $1 \mathrm{a}$ & \multirow{5}{*}{$\begin{array}{l}\text { WISC- } \\
\text { IV }\end{array}$} & FsIQ & $\begin{array}{l}\text { Gender } \\
\text { Maternal education }\end{array}$ & $\begin{array}{l}0.41(1) \\
34,2(1)\end{array}$ & $\begin{array}{l}0.526 \\
<0.0001\end{array}$ \\
\hline \multirow{4}{*}{$1 b$} & & $\mathrm{VCI}$ & $\begin{array}{l}\text { Gender } \\
\text { Maternal education }\end{array}$ & $\begin{array}{l}0.41(1) \\
35,96(1)\end{array}$ & $\begin{array}{l}0.518 \\
<0.0001\end{array}$ \\
\hline & & PeRI & $\begin{array}{l}\text { Gender } \\
\text { Maternal education }\end{array}$ & $\begin{array}{l}0.52(1) \\
23,52(1)\end{array}$ & $\begin{array}{l}0.472 \\
<0.0001\end{array}$ \\
\hline & & WMI & $\begin{array}{l}\text { Gender } \\
\text { Maternal education }\end{array}$ & $\begin{array}{l}0.07(1) \\
8.13(1)\end{array}$ & $\begin{array}{l}0.788 \\
0.006\end{array}$ \\
\hline & & PrSI & $\begin{array}{l}\text { Gender } \\
\text { Maternal education }\end{array}$ & $\begin{array}{l}0.9(1) \\
11,51(1)\end{array}$ & $\begin{array}{l}0.347 \\
0.001\end{array}$ \\
\hline \multirow[t]{4}{*}{ 1c } & \multirow{4}{*}{$\begin{array}{l}\text { Corsi } \\
\text { Block } \\
\text { Tapping } \\
\text { Task }\end{array}$} & $\begin{array}{l}\text { Reaction time } \\
\text { (sec) forward }\end{array}$ & $\begin{array}{l}\text { Gender } \\
\text { Maternal education }\end{array}$ & $\begin{array}{l}0.27(1) \\
0.002(1)\end{array}$ & $\begin{array}{l}0.603 \\
0.966\end{array}$ \\
\hline & & $\begin{array}{l}\text { Correct items } \\
\text { (number) forward }\end{array}$ & $\begin{array}{l}\text { Gender } \\
\text { Maternal education }\end{array}$ & $\begin{array}{l}1.29(1) \\
7,52(1)\end{array}$ & $\begin{array}{l}0.260 \\
0.008\end{array}$ \\
\hline & & $\begin{array}{l}\text { Reaction time } \\
\text { (sec) backward }\end{array}$ & $\begin{array}{l}\text { Gender } \\
\text { Maternal education }\end{array}$ & $\begin{array}{l}0.05(1) \\
0.09(1)\end{array}$ & $\begin{array}{l}0.825 \\
0.76\end{array}$ \\
\hline & & $\begin{array}{l}\text { Correct items } \\
\text { (number) } \\
\text { backward }\end{array}$ & $\begin{array}{l}\text { Gender } \\
\text { Maternal education }\end{array}$ & $\begin{array}{l}3.37(1) \\
20.75(1)\end{array}$ & $\begin{array}{l}0.071 \\
<0.0001\end{array}$ \\
\hline \multirow[t]{3}{*}{$1 d$} & \multirow[t]{3}{*}{ WCST } & $\begin{array}{l}\text { Completed } \\
\text { categories } \\
\text { (number) }\end{array}$ & $\begin{array}{l}\text { Gender } \\
\text { Maternal education }\end{array}$ & $\begin{array}{l}1.13(1) \\
2.08(1)\end{array}$ & $\begin{array}{l}0.290 \\
0.153\end{array}$ \\
\hline & & $\begin{array}{l}\text { Number of } \\
\text { perseverational } \\
\text { errors }\end{array}$ & $\begin{array}{l}\text { Gender } \\
\text { Maternal education }\end{array}$ & $\begin{array}{l}3.06(1) \\
0.27(1)\end{array}$ & $\begin{array}{l}0.084 \\
0.608\end{array}$ \\
\hline & & $\begin{array}{l}\text { Number of non- } \\
\text { perseverational } \\
\text { errors }\end{array}$ & $\begin{array}{l}\text { Gender } \\
\text { Maternal education }\end{array}$ & $\begin{array}{l}0.78(1) \\
0.24(1)\end{array}$ & $\begin{array}{l}0.381 \\
0.627\end{array}$ \\
\hline
\end{tabular}

Note: ELBW = extremely low birth weight $(<1000$ grams), VLBW = very low birth weight (1000-1499 grams), WISC-IV = Wechsler Intelligence Scales for Children, FSIQ = Full Scale $\mathrm{IQ}, \mathrm{VCI}=$ Verbal Comprehension Index, PeRI = Perceptual Reasoning Index, WMI = Working Memory Index, PrSI = Processing Speed Index, WCST $=$ Wisconsin Card Sorting Test. 
In the models consisting only the preterm groups (Table 4) maternal education remained a significant covariate. After entering birth weight (BW) as a categorical variable dividing the preterm children into VLBW and ELBW subgroups BW had no significant linear effect on any of the dependent variables. Gestational age, intraventricular haemorrhage, and rethinopathy of prematurity had no significant contribution either.

Children with BPD had lower scores in the WISC-IV Full Scale IQ, Perceptual Reasoning Index, and Processing Speed Index. In addition, they completed fewer categories and made more perseverational errors in the WCST. The small for gestational age children scored higher in the WISC-IV Verbal Comprehension Index and had shorter reaction times in the Corsi Block Tapping Task.

Table 4. General Linear Models: Preterm sample

\begin{tabular}{|c|c|c|c|c|c|}
\hline Model & & Measure & Independent & $F(\mathrm{df})$ & $p$ \\
\hline $2 a$ & WISC-IV & FsIQ & $\begin{array}{c}\text { BW } \\
\text { GA } \\
\text { IVH } \\
\text { ROP } \\
\text { BPD } \\
\text { SGA }\end{array}$ & $\begin{array}{c}1.04(1) \\
0.1(1) \\
0.5(1) \\
2.03(1) \\
10.38(1) \\
3.07(1)\end{array}$ & $\begin{array}{l}0.318 \\
0.757 \\
0.484 \\
0.167 \\
0.004 \\
0.092\end{array}$ \\
\hline $2 b$ & & $\mathrm{VCI}$ & $\begin{array}{c}\text { BW } \\
\text { GA } \\
\text { IVH } \\
\text { ROP } \\
\text { BPD } \\
\text { SGA }\end{array}$ & $\begin{array}{l}0.09(1) \\
0.87(1) \\
0.39(1) \\
0.02(1) \\
2.75(1) \\
4.51(1)\end{array}$ & $\begin{array}{l}0.762 \\
0.360 \\
0.536 \\
0.880 \\
0.110 \\
0.044\end{array}$ \\
\hline & & PeRI & $\begin{array}{c}\text { BW } \\
\text { GA } \\
\text { IVH } \\
\text { ROP } \\
\text { BPD } \\
\text { SGA }\end{array}$ & $\begin{array}{c}0.43(1) \\
1.02(1) \\
0.01(1) \\
2.8(1) \\
4.99(1) \\
1.71(1)\end{array}$ & $\begin{array}{l}0.518 \\
0.323 \\
0.930 \\
0.107 \\
0.035 \\
0.203\end{array}$ \\
\hline & & WMI & $\begin{array}{c}\text { BW } \\
\text { GA } \\
\text { IVH } \\
\text { ROP } \\
\text { BPD } \\
\text { SGA }\end{array}$ & $\begin{array}{l}1.13(1) \\
0.69(1) \\
0.40(1) \\
0.72(1) \\
4.07(1) \\
0.18(1)\end{array}$ & $\begin{array}{l}0.297 \\
0.414 \\
0.532 \\
0.403 \\
0.054 \\
0.678\end{array}$ \\
\hline & & PrSI & $\begin{array}{l}\text { BW } \\
\text { GA } \\
\text { IVH } \\
\text { ROP } \\
\text { BPD } \\
\text { SGA }\end{array}$ & $\begin{array}{c}0.29(1) \\
0.20(1) \\
0.79(1) \\
2.03(1) \\
11.27(1) \\
1.21(1)\end{array}$ & $\begin{array}{l}0.594 \\
0.655 \\
0.381 \\
0.167 \\
0.003 \\
0.281\end{array}$ \\
\hline
\end{tabular}




\begin{tabular}{|c|c|c|c|c|c|}
\hline Model & \multicolumn{2}{|c|}{ Measure } & Independent & $F(\mathrm{df})$ & $p$ \\
\hline \multirow[t]{4}{*}{$2 c$} & \multirow[t]{4}{*}{$\begin{array}{l}\text { Corsi } \\
\text { Block } \\
\text { Tapping } \\
\text { Task }\end{array}$} & $\begin{array}{l}\text { Reaction time } \\
\text { (sec) } \\
\text { forward }\end{array}$ & $\begin{array}{l}\text { BW } \\
\text { GA } \\
\text { IVH } \\
\text { ROP } \\
\text { BPD } \\
\text { SGA }\end{array}$ & $\begin{array}{l}1.70(1) \\
3.50(1) \\
0.62(1) \\
2.81(1) \\
0.49(1) \\
6.25(1)\end{array}$ & $\begin{array}{l}0.204 \\
0.074 \\
0.437 \\
0.107 \\
0.491 \\
0.020\end{array}$ \\
\hline & & $\begin{array}{l}\text { Correct trials } \\
\text { (number) } \\
\text { forward }\end{array}$ & $\begin{array}{l}\text { BW } \\
\text { GA } \\
\text { IVH } \\
\text { ROP } \\
\text { BPD } \\
\text { SGA }\end{array}$ & $\begin{array}{c}0.99(1) \\
0.90(1) \\
0.00(1) \\
0.16(1) \\
0.74(1) \\
0.20(1)\end{array}$ & $\begin{array}{l}0.331 \\
0.353 \\
0.997 \\
0.692 \\
0.787 \\
0.661\end{array}$ \\
\hline & & $\begin{array}{l}\text { Reaction time } \\
\text { (sec) } \\
\text { backward }\end{array}$ & $\begin{array}{l}\text { BW } \\
\text { GA } \\
\text { IVH } \\
\text { ROP } \\
\text { BPD } \\
\text { SGA }\end{array}$ & $\begin{array}{c}0.19(1) \\
1.16(1) \\
0.45(1) \\
1.53(1) \\
0.14(1) \\
13.91(1)\end{array}$ & $\begin{array}{l}0.669 \\
0.292 \\
0.509 \\
0.228 \\
0.712 \\
0.001\end{array}$ \\
\hline & & $\begin{array}{l}\text { Correct trials } \\
\text { (number) } \\
\text { backward }\end{array}$ & $\begin{array}{l}\text { BW } \\
\text { GA } \\
\text { IVH } \\
\text { ROP } \\
\text { BPD } \\
\text { SGA }\end{array}$ & $\begin{array}{l}0.00(1) \\
0.96(1) \\
0.04(1) \\
0.38(1) \\
0.22(1) \\
0.35(1)\end{array}$ & $\begin{array}{c}0.951 \\
0.337 \\
0.74 \\
0.541 \\
0.644 \\
0.558 \\
\end{array}$ \\
\hline \multirow[t]{3}{*}{$2 d$} & \multirow[t]{3}{*}{ WCST } & $\begin{array}{l}\text { Completed } \\
\text { categories } \\
\text { (number) }\end{array}$ & $\begin{array}{l}\text { BW } \\
\text { GA } \\
\text { IVH } \\
\text { ROP } \\
\text { BPD } \\
\text { SGA }\end{array}$ & $\begin{array}{l}0.26(1) \\
0.09(1) \\
0.49(1) \\
0.03(1) \\
4.51(1) \\
1.11(1)\end{array}$ & $\begin{array}{l}0.612 \\
0.761 \\
0.489 \\
0.859 \\
0.044 \\
0.303\end{array}$ \\
\hline & & $\begin{array}{l}\text { Number of } \\
\text { perseverational } \\
\text { errors }\end{array}$ & $\begin{array}{l}\text { BW } \\
\text { GA } \\
\text { IVH } \\
\text { ROP } \\
\text { BPD } \\
\text { SGA }\end{array}$ & $\begin{array}{l}0.43(1) \\
2.10(1) \\
0.21(1) \\
0.44(1) \\
8.21(1) \\
0.20(1) \\
\end{array}$ & $\begin{array}{l}0.520 \\
0.159 \\
0.650 \\
0.514 \\
0.008 \\
0.661 \\
\end{array}$ \\
\hline & & $\begin{array}{l}\text { Number of } \\
\text { non- } \\
\text { perseverational } \\
\text { errors }\end{array}$ & $\begin{array}{l}\text { BW } \\
\text { GA } \\
\text { IVH } \\
\text { ROP } \\
\text { BPD } \\
\text { SGA }\end{array}$ & $\begin{array}{l}2.75(1) \\
0.00(1) \\
0.06(1) \\
0.93(1) \\
2.92(1) \\
0.57(1)\end{array}$ & $\begin{array}{l}0.110 \\
0.997 \\
0.811 \\
0.343 \\
0.100 \\
0.459\end{array}$ \\
\hline
\end{tabular}

Note: ELBW = extremely low birth weight $(<1000$ grams), VLBW $=$ very low birth weight $(1000-$ 1499 grams), $\mathrm{BW}=$ birth weight, $\mathrm{GA}=$ gestational age, $\mathrm{IVH}=$ intraventricular haemorrhage, $\mathrm{ROP}$ $=$ retinopathy of prematurity, $\mathrm{BPD}=$ bronchopulmonary dysplasia, $\mathrm{SGA}=$ small for gestational age, WISC-IV $=$ Wechsler Intelligence Scales for Children, FSIQ $=$ Full Scale IQ, VCI $=$ Verbal Comprehension Index, PeRI = Perceptual Reasoning Index, WMI = Working Memory Index, PrSI $=$ Processing Speed Index, WCST $=$ Wisconsin Card Sorting Test. 


\section{Discussion}

The aim of our study was to evaluate the school-age outcomes of Hungarian preterm children in basic cognitive abilities and executive functions as compared to typically developing full-term children. The preterm children were born with birthweights below 1500 grams. They were divided into two groups, the first group consisted of the children with very low birth weights (VLBW, 1000-1499 grams) while the children in the second group had extremely low birth weights (ELBW, BW $<1000$ grams). Some of them suffered certain perinatal complications - mostly of milder degrees (Table 1 ), and they were free from serious CNS injuries. We were attempting to tap the background of individual differences by analysing the effects of perinatal and social-economic factors on the performances.

Following recommendations in the literature (Ford et al 2011; Ritter et al., 2013) we decided to test children born within a one-year interval rather than covering a larger age range. The reasons of choosing the age of 9-10 years were manifold. In spite of the major changes occurring in cognitive development around 9 years there was little information available on the executive functions in preterm children of this age. Moreover, a curious inconsistence in the past research rendered this age specifically interesting. According to brain imaging data there were no differences between 8-yearold preterm and term children in dorsal prefrontal and orbitofrontal volumes (Peterson et al., 2000), nevertheless 8-10-year-old VLBW children performed significantly poorer than the controls in tasks measuring executive functions (Aarnoudse-Moens et al., 2011; Ritter et al., 2013).

The mean IQ of our VLBW/ELBW preterm subjects fell in the average range and it was true also for the subscale scores of the WISC-IV (Table 2), similarly to the results published by Grunewaldt et al. (2014) and Stålnacke et al. (2018). However, the picture is really reassuring only as far as our VLBW subgroup is considered. According to a recent meta-analysis reviewing 71 studies which compared the IQs of very preterm children to those of term comparison groups the preterms significantly lagged behind (Twilhaar et al., 2018), and same applies to our ELBW children who had a mean Full-Scale IQ significantly lower as compared not only to the IQ of the term controls but even to that of their VLBW counterparts. The deficits of our ELBW children in the Full-Scale IQ mainly stemmed from poorer performances in Processing Speed and Perceptual Reasoning. It is also notable that there were massive within-group scatters with particularly some ELBW preterms scoring rather low.

Out of the tested factors of executive function the ELBW children displayed a certain shortcoming in spatial-visual working memory (fewer correct items in the Corsi blocks backward task). This result is in line with findings published by Ford and colleagues (2011), Stålnacke and colleagues 
(2018), and Ritter and colleagues (2013). However, in the light of the performances of the older (10-13 years old) subjects in the Ritter et al. (2013) study in our 9-10 year-old preterms the underachievement may still reflect a delay rather than a deficit. In cognitive flexibility (cognitive set shifting, Wisconsin Card Sorting Test) our preterm children performed at the same level as their controls. Our results support the model that differentiates the EF into two separable major components which may follow distinct developmental pathways over time (Stålnacke et al., 2018). In cognitive flexibility even our ELBW preterms seem to have caught up with the nonrisk counterparts by $9-10$ years of age that Ritter and colleagues (2013) found only in their 10-13 year-olds.

In search for the explanation of the individual variability of the EF development the links between the outcome measures and the available background variables (gender, maternal education, perinatal characteristics and complications) were examined. Using the variables which proved meaningful, General Linear Models were computed. Maternal education was a significant covariate for the full-scale IQ and within it for each measured component, and also for spatial-visual working memory. The impact of socio-economic conditions, notably maternal education on children's intelligence is generally acknowledged, and the heightened role of social factors in the development of preterm children has been widely documented (e.g. Kalmár, 2007; O’Meagher et al., 2017). Our results provide partial support for other studies which found that socio-economic background influenced the development of the executive functions as well (Ford et al., 2011; Miyake \& Friedman, 2012; O’Meagher et al., 2017; Stålnacke et al., 2018).

The role of birthweight is worth of attention. Using it as a categorical variable (VLBW vs ELBW) the result of the analysis pointed to a heightened vulnerability of children born with birthweights below 1000 grams. On the other hand, after dividing the preterm children into the above subgroups, birthweight had no linear effect on the outcome. The ELBW subgroup had shorter mean gestation (although the range was overlapping with that of the VLBW children), but in the multivariate analysis gestational age did not prove to be significant either. Neither intraventricular haemorrhage nor rethinopathy of prematurity had any significant main effect on the measured abilities. It may be explained by the scarcity of the more severe degrees of these complications in our preterm sample, and it is good news that in the milder cases the perinatal medical care seems to be efficient. In contrast, bronchopulmonal dysplasia was identified as underlying deficits both in intelligence and executive functions which is in line with other recently published results (e.g. Sriram et al., 2018, and the meta-analysis by Twilhaar et al., 2018). As BPD only occurred in ELBW children it may be the factor responsible for the poorer performances of the ELBW preterms in 
Processing Speed and Perceptual Reasoning, as well as in cognitive flexibility as indicated by the WCST scores. BPD causes a chronic hypoxia which is likely to be responsible for its untoward long-term effects (Deakins, 2009). In the background of the cognitive and executive function deficits of the ELBW children it is very hard to disentangle the impacts of various factors such as premature birth, extremely low birthweight, perinatal complications, and potentially also social disadvantages.

The main conclusions of the study are the following. On the one hand, our results suggest that the birthweight classification of preterm children is meaningful even as late as in 9-10 years of age, in evaluating the long-term outcomes it is far more informative than using birthweight as a numerical variable. The children born below 1000 grams are at particular risk of compromised cognitive and executive function development. On the other hand, the massive scatter behind the group mean values, especially in the light of the variability of developmental trends (Costa et al., 2017) is a serious warning that risk children need individual attention and should be followed up at least until their late school years.

\section{Limitations of the study}

Our sample was not representative in various aspects. In maternal education it was biased towards the higher levels which is not a unique problem as it is usually difficult to secure the cooperation of parents with lower education. In addition, our preterm groups were not representative of the respective birthweight categories. The composition of the samples is a common problematic issue of the research with atypical subjects due to the enormous individual variability of the factors directly or indirectly related to the target independent variable. We hope that despite the necessary compromises the careful multivariate analysis helped to interpret our findings reliably. It would have been of interest to check the effects of intervention. Unfortunately the participation in intervention (whether or not, method, duration, etc.) varied across subjects to an extent that it was not feasible to handle.

\section{References}

Aarnoudse-Moens, C.S.H., Duivenvoorden, H.J., Weisglas-Kuperus, N., Van Goudoever, J.B., \& Oosterlaan, J. (2011). The profile of executive function in very preterm children at 4 to 12 years. Developmental Medicine and Child Neurology, 54(3), 247-253.

Balla, Gy. \& Szabó, M (2013). A koraszülöttek krónikus utóbetegségei. Orvosi Hetilap, 154(38), 1498-1511. 
Beauchamp, M.H., Thompson, D.K., Howard, K., Doyle, L.W., Egan, G.F., Inder, P.J., et al (2008). Preterm infant hippocampal volumes correlate with later working memory deficits. Brain, 131(11), 2986-2994.

Behrman, R.E., \& Butler, A.S. (Eds.) (2007). Preterm Birth. Causes, consequences, and prevention. Washington: The National Academic Press

Beke, A. (2019). A fokozottan veszélyeztetett csecsemők és kisgyermekek gondozási rendszerének jelentősége a rehabilitáció korai indításában. In Zs.Vekerdy-Nagy (Ed.), A gyermekrehabilitáció sajátosságai (515-528). Budapest: Medicina

Blair, C., \& Razza, R.P. (2007). Relating effortful control, executive function, and false belief understanding to emerging math and literacy ability in kindergarten. Child development, 78(2), 647-663.

Corsi, P.M. (1972). Human memory and the medial temporal region of the brain. Dissertation Abstracts International, 34(2-B), 891.

Costa, D.S., Miranda, D.M., Burnett, A.C., Doyle, L.W., Cheong, J.L.Y., \& Anderson, P.J. (2017). Executive functions and academic outcomes in children who were extremely preterm. Pediatrics, 140(3): e20170257.

De Kieviet, J.F., Zoetebier, L., Van Elburg, R.M., Vermeulen, R.J., \& Oosterlaan, J. (2012). Brain development of very preterm and very low-birthweight children in childhood and adolescence: A meta-analysis. Developmental Medicine and Child Neurology, 54(4), 313-323.

Deakins, K.M. (2009). Bronchopulmonary dysplasia. Respiratory Care, 54(9), 1252-1262.

Diamond, A. (2013). Executive functions. Annual Review of Psychology, 64, 135-168.

Ertl, T. (2018). A kora- és retardált újszülött ellátása. Az életképesség határa. Korai és hoszszú távú következmények. In Z. Papp (Ed.), A perinatológia kézikönyve (387-400). Budapest: Medicina

Feldman, H.M., Lee, E.S., Yeatman., J.D., \& Yeom, K.W. (2012). Language and reading skills in school-aged children and adolescents born preterm are associated with white matter properties on diffusion tensor imagine. Neuropsychologia, 50(14), 3348-3362.

Ford, R.M., Neulinger, K., O'Callaghan, M., Mohay, H., Gray, P. \& Shum, D. (2011). Executive function in 7-9-year-old children born extremely preterm or with extremely low birth weight: effects of biomedical history, age at assessment, and socioeconomic status. Archives of Clinical Neuropsychology, 26(7), 632-644.

Glass, H.C., Costarino, A.T., Stayer, S.A., Brett, C., Cladis, F., \& Davis, P.J. (2015). Outcomes of extremely premature infants. Anesthesia and Analgesia, 120(6), 1337-1351.

Grant, D.A., \& Berg, E.A. (1948). A behavioral analysis of reinforcement and ease of shifting to new responses in a Weigel-type card-sorting problem. Journal of Experimental Psychology, 38, 404-411.

Grunewaldt, K.H., Fjørtoft, T., Bjuland, K.J., Brubakk, A., Eikenes, L., Håberg, A.K., et al. (2014). Follow-up at 10 years in ELBW children - functional outcome, brain morphology and results from motor assessments in infancy. Early Human Development, 90(10), 571-578.

Hargitai, B., \& Marton, T. (2018). Perinatális patológia. In Z. Papp (Ed.), A perinatológia kézikönyve (727-763). Budapest: Medicina

Heaton, R.K., Chelune, G.J., Talley, J.L., Kay, G., \& Curtiss, G. (1993). Wisconsin Card Sorting Test Manual: Revised and Expanded. Odessa, FL: Psychological Assessment Resources

Hungarian Central Statistical Office (HCSO). (2018). Data of live birth by district. Retrieved March 01, 2019, from: http:/ / statinfo.ksh.hu/Statinfo/haViewer.jsp?lang = en

Kalmár, M. (2007). Az intelligencia alakulásának előrejelezhetősége és váratlan fordulatai. Rizikómentesen született, valamint koraszülött gyermekek követésének tanulságai. Budapest: ELTE Eötvös Kiadó 
Milner, B. (1971). Interhemispheric differences in the localization of psychological processes in man. British Medical Bulletin, 27(3), 272-277.

Miyake, A., \& Friedman, N.P. (2012). The nature and organization of individual differences in executive functions: four general conclusions. Current directions in Psychological Science, 21(1), 8-14.

Mueller, S.T., Piper, B.J. (2014). The Psychology Experiment Building Language (PEBL) and PEBL Test Battery. Journal of Neuroscience Methods, 222(2), 250-259.

Mulder, H., Pitchford, N.J., Hagger, M.S., \& Marlow, N. (2009). Development of executive function and attention in preterm children: a systematic review. Developmental Neuropsyhology, 34(4), 393-421.

O'Meagher, S., Kemp, N., Norris, K., Anderson, P., \& Skilbeck, C. (2017). Risk factors for executive function difficulties in preschool and early school-age preterm children. Acta Paediatrica, 106(9), 1468-1473.

Peterson, B.S., Vohr, B., Staib, L.H., Cannistraci, C.J., Dolberg, A., Schneider, K.C., et al. (2000). Regional brain volume abnormalities and long-term cognitive outcome in preterm infants. JAMA, 284(15), 1939-1947.

Ritter, B.C., Nelle, M., Perrig, W., Steinlin, M., \& Everts, R. (2013). Executive functions of children born very preterm - deficit or delay? European Journal of Pediatrics, 172(4), 473483.

Rushe, T.M., Rifkin, L., Stewart, A.L., Townsend, J.P., Roth, S.C., Wyatt, J.S., et al. (2001). Neuropsychological outcome at adolescence of very preterm birth and its relation to brain structure. Developmental Medicine and Child Neurology, 43(4), 226-233.

Skranes, J., Løhaugen, G.C.C., Evensen, K.A.I., Evensen, K.A.i., Indredavik, M.S., Haraldseth, O., et al. (2012). Entorhinal cortical thinning affects perceptual and cognitive functions in aldolescents born preterm with very low birth weight (VLBW). Early Human Development, 88(2), 103-109.

Sriram, S., Schreiber, M.D., Msall, M.E., Kuban, K.C.K., Joseph, R.M., O'Shea, T.M., et al. (2018). Cognitive development and quality of life associated with BPD in 10-years-olds born preterm. Pediatrics, 141(6): e20172719.

Stålnacke, J., Lundequist, A., Böhm, B., Frossberg, H., \& Smedler, A.C. (2018). A longitudinal model of executive function development from birth through adolescence in children born very or extremely preterm. Child Neuropsychology, 25(3), 318-335.

Twilhaar, E.S., Wade, R.M., de Kieviet, J.F., van Goudoever, J.B., van Elburg, R.M., \& Oosterlaan, J. (2018). Cognitive outcomes of children born extremely or very preterm since 1990s and associated risk factors. A meta-analysis and meta-regression. JAMA Pediatrics, 172(4), 361-367.

Walsh, M.C., Szefler, S., Davis J., Allen, M., Van Marter, L., Abman, S., et al. (2006). Summary proceedings from Bronchopulmonary Dyslpasia Group. Pediatrics, 117(3), 52-56.

Wechsler, D. (2008). Wechsler Gyermek Intelligenciateszt. Negyedik kiadás. Budapest: OS Hungary Tesztfejlesztő Kft.

World Health Organization (WHO) (2018). Preterm birth. Retrieved October 10, 2018, from: http://www.who.int/news-room/fact-sheets/detail/preterm-birth

Zelazo, P.D., Carlson, S.M., \& Kesek, A. (2008). Development of executive function in childhood. In C.A. Nelson, \& M. Luciana, (Eds.), Handbook of developmental cognitive neuroscience (553-575). London: A Bradford Book, The MIT Press 


\title{
Acknowledgments
}

The authors wish to thank Dr. Miklós Győri for making the devices of the digital tests available, for Prof. László Hunyadi for his advices in the statistical analysis, and for Viktória Klein and Nikolett Koller for their help with data input. The cooperation of the children and their parents is deeply appreciated.

\section{Division of Labor}

Nagy, A.: study design, concept of the article, data collection, data analysis, preparation of all sections of the article. Kalmár, M.: data analysis, preparation of the article, supervision. Beke A.M., Gráf, R.: review of the article. Horváth, E.: data analysis.

\section{Conflict of interests statement}

The authors have no conflict of interest to declare.

\section{Igen alacsony születési súlyú és extrém alacsony születési súlyú koraszülöttek intelligenciájának és végrehajtó funkcióinak vizsgálata 9-10 éves korban}

\author{
NAGY ANETT - KALMÁR MAGDA - BEKE ANNA MÁRIA - \\ GRÁF RÓZSA - HORVÁTH ENDRE
}

Elméleti háttér: A koraszülöttségre igen jelentős kutatási érdeklődés irányul, mivel ez a leggyakoribb perinatális rizikó, amely a zavartalan fejlődést veszélyezteti. A koraszülöttség hosszú távú hatására vonatkozóan azonban megoszlanak a kutatási eredmények. Lehetséges, hogy a koraszülött gyermekek iskolai teljesítményproblémáinak hátterében a kognitív és a végrehajtó funkciók fejlődésének zavara áll. Cél: Iskoláskorú, magyar, extrém alacsony és igen alacsony születési súlyú koraszülöttek kognitív képességeinek és végrehajtó funkcióinak felmérése, összehasonlítva tipikusan fejlődő, időre született gyermekek teljesítményével, továbbá a fejlődést befolyásoló háttértényezők azonosítása. Módszer: 54 koraszülött gyermek (két csoport: 27 fó extrém alacsony születési súlyú, 27 fó igen alacsony születési súlyú) és a csoportokhoz nemben, életkorban és az anya iskolai végzettségében illesztett 27 időre született, tipikusan fejlődő gyermek vizsgálata történt 9-10 éves korukban a Wechsler-féle intelligenciateszttel (WISC-IV), valamint a Corsi kockák teszt és a Wisconsin kártyaszortírozó teszt digitalizált verziójával. A háttértényezők elemzése kiterjedt a születési súlyra, a gesztációs korra, a perinatális szövődményekre és az anya iskolai végzettségére. Eredmények: A WISC-IV intelligenciateszt minden mutatójának átlaga mindhárom csoport esetében a normál övezetbe esett. Az extrém alacsony születési súlyú koraszülötteknek azonban a többiekhez viszonyítva fejlődési hátránya mutatkozott: a teljes IQ és a feldolgozási sebesség mutatókban mindkét másik csoportnál szignifikánsan gyengébb eredményt értek el, míg a perceptuális következtetés indexben és a téri-vizuális munkamemóriában az időre született kontrollcsoporthoz képest teljesítettek szignifikánsan 
rosszabbul. A háttértényezők közül a perinatális szövődmények és az anya iskolai végzettsége bizonyultak meghatározónak. Konklúzió: A javuló perinatális ellátás következtében a koraszülötteknek jó esélyük van a megfelelő fejlődésre. Azonban nem hagyhatók figyelmen kívül a koraszülött csoporton belüli nagy egyéni különbségek és a fejlődést befolyásoló környezeti tényezők, amelyek befolyásolhatják a kognitív és a végrehajtó funkciók fejlődését. Az 1000 gramm alatti születési súly jelentős rizikó, főleg, ha perinatális szövődmények is kialakulnak a koraszülöttnél.

Kulcsszavak: koraszülöttség, IQ, munkamemória, kognitív flexibilitás, perinatális szövődmények

This is an open-access article distributed under the terms of the Creative Commons Attribution 4.0 International License (https://creativecommons.org/licenses/by/4.0/), which permits unrestricted use, distribution, and reproduction in any medium, provided the original author and source are credited, a link to the CC License is provided, and changes - if any - are indicated. (SID_1) 